DOI: $10.2478 / \mathrm{v} 10014-011-0022-8$

COBISS Code 1.01

Agrovoc descriptors: maize, zea mays, genetically modified organisms, sustainability, cropping systems, crop management, contamination, environmental factors, cultural methods, alternative agriculture

Agris category code: F30, F01

\title{
Adventitious presence of GMOs in maize in the view of coexistence
}

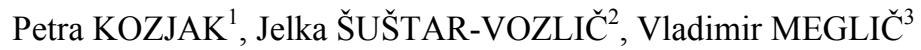

Received: April 19, 2011; accepted: September 14, 2011. Prispelo 19. aprila 2011; sprejeto: 14. septembra 2011.

\begin{abstract}
The introduction of genetically modified (GM) crops in the European Union (EU) demand specific management. The EU recommendations for the management of different agricultural practices are oriented towards the sustainable agriculture in the frame of flexible coexistence. Coexistence may be affected by the adventitious presence of genetically modified organisms (APGM) in non-GM crops along the supply chain. Various biological and environmental parameters as well as technical management have influence on the occurrence and the degree of APGM. These parameters are being used for the development of preventive coexistence measures in individual EU countries. Applicability of the prescribed coexistence measures is critically reviewed, also in the view of possible introduction of GM maize cultivation in Slovenia. From the review, it is concluded that some coexistence measures are not in line with coexistence principles because they demand excessive work and are sometimes difficult to implement in practice. Alternative cooperation of different cropping systems are discussed for potential future implementation. The review is focused on maize, the predominant GM crop cultivated in the EU and an interesting crop for cultivation in Slovenia.
\end{abstract}

Key words: coexistence, GMO, adventitious presence of GMOs, maize

\section{IZVLEČEK}

\section{NENAMERNA PRISOTNOST GENSKO SPREMENJENE KORUZE IN MOŽNOSTI SOOBSTOJA}

\begin{abstract}
Uvajanje gensko spremenjenih (GS) rastlin $\mathrm{v}$ pridelavo $\mathrm{v}$ Evropski uniji (EU) zahteva posebne ukrepe za zagotavljanje soobstoja različnih sistemov pridelovanja. Evropska priporočila za soobstoj spodbujajo upravljanje različnih pridelovalnih sistemov $\mathrm{v}$ smeri trajnostnega kmetijstva. $\mathrm{Na}$ soobstoj vpliva naključna, nenamerna prisotnost gensko spremenjenih organizmov (APGM) v gensko nespremenjenih pridelkih in proizvodih vzdolž celotne pridelovalne verige. $\mathrm{Na}$ prisotnost in stopnjo APGM vplivajo številni dejavniki, kot so biološki in okoljski ter načini upravljanja. $\mathrm{Na}$ podlagi teh dejavnikov so pripravljeni ukrepi za zagotavljanje soobstoja različnih kmetijskih praks. Podrobneje smo pregledali uporabnost posameznih ukrepov v luči možnosti uvedbe pridelovanja gensko spremenjene koruze $\mathrm{v}$ Sloveniji. Iz preglednega prispevka ugotavljamo, da nekateri ukrepi niso $\mathrm{v}$ skladu s temeljnimi načeli soobstoja, da zahtevajo ogromno dela in so zato $\mathrm{v}$ praksi težko izvedljivi. V razpravi smo predstavili alternativne načine upravljanja kmetijskih praks, ki bi jih lahko izvajali $\mathrm{v}$ prihodnosti. $\mathrm{V}$ prispevku smo se osredotočili na koruzo, ki je prevladujoča gensko spremenjena poljščina v EU in najbolj zanimiva za uvajanje v Sloveniji.
\end{abstract}

Ključne besede: soobstoj, GSO, naključna prisotnost GSO, koruza

\footnotetext{
1 PhD., Agricultural Institute of Slovenia, Dep. for Crop and Seed Science, Hacquetova 17, SI-1000 Ljubljana, Slovenia, petra.kozjak@kis.si

2 PhD., Doc. Agricultural Institute of Slovenia, Dep. for Crop and Seed Science, Hacquetova 17, SI-1000 Ljubljana, Slovenia, jelka.sustarvozlic@kis.si

3 PhD., Doc. Agricultural Institute of Slovenia, Dep. for Crop and Seed Science, Hacquetova 17, SI-1000 Ljubljana, Slovenia, vladimir.meglic@kis.si
} 


\section{INTRODUCTION}

In the last two decades, in the European Union (EU) cultivation of genetically modified organisms (GMOs) has become one of the cropping systems in addition to conventional and organic crop production. In the EU, two GMO events are approved for cultivation, MON810 maize and Amflora potato. In 2009, MON 810 maize was cultivated on 94.750 ha, which is a slight decrease compared to the previous years due to the moratorium in individual EU countries (GMO Compass, 2010). Although GM maize is produced on less than $1 \%$ of the total maize cultivation area in Europe, GM cultivation presents concerns to the EU consumers since they perceive potential risk for the environment, animal and human health. To ensure consumer's freedom of choice between GM and non-GM products labelling is required in the EU for all products that contain GMOs (Regulation EC No. 1830/2003). Due to possibilities for unintentional and technically unavoidable presence of GMOs (i.e. adventitious presence of genetically modified organisms - APGM), tolerance thresholds are prescribed for food and feed; labelling is required for all the products that exceeds $0.9 \%$ of GMOs (Regulation EC No. 1829/2003). However, even lower contractual thresholds are used in practice within the supply chain (Recommendation 2010/C. 200/01). The presence of GM in non-GM crop may cause economic losses to farmers that trade the product as non-GM, loss of the market and legal disputes.

The introduction of GM crops in agriculture poses several questions how to manage the coexistence of different cropping systems. According to the EU Guidelines on general measures for ensuring coexistence (Recommendation EC 2003/556/EC) and subsequent Commission recommendations on guidelines for the development of national co-existence measures (Recommendation 2010/C. 200/01) farmers should be able to cultivate the types of agricultural crops they choose, GM, conventional or organic. Since there are different agricultural production practices and environmental conditions, individual EU countries can define their own national strategies for managing coexistence.

Many field experiments have been carried out in the last decades in order to gather data for the reliable sciencebased technical measures of coexistence (Henry et al., 2003; Melé 2004; Weekes et al., 2007; Della Porta et al., 2008; Langhof et al., 2010). However, these results are not always considered in the legislation that is currently in place in individual EU countries. Certain technical measures are difficult to be applied in practice due to organisational and logistic problems and difficulties in implementing in diverse environments (e.g. isolation distances). The coexistence of GM and non-GM crops/products downstream the supply chain is proven to be technically manageable, while the monitoring of APGM in the field is far from being resolved (Co-Extra project, 2005-2009).

Slovenia is characterized by fragmented landscape with an average field size of 1.4 ha as well as with specific and diverse environmental conditions, therefore specific co-existence measures need to be implemented. The Act on coexistence of GM plants with other crops is in place since 2009 (ZSGSROKR, 2009). Sub legislation acts were adopted in 2010/2011 (e.g. detailed measures for cultivation of GM maize). However, there has been no cultivation and no field trials with GM crops yet.

The aim of the article is to review the sources and parameters influencing APGM in maize cultivation and to discuss different coexistence measures in the view of implementation in practice. The results of several scientific studies are gathered in order to reveal the gaps and needs of existing coexistence measures. The review is focused on maize, since among the currently approved GM crops; maize is the most interesting for cultivation in Slovenia.

\section{ADVENTITIOUS PRESENCE OF GMOS}

The adventitious presence of genetically modified organisms (APGM) in the environment and within the supply chain is unavoidable due to biological characteristics of plants, open nature of the field and technical management along the supply chain from sowing in the field to harvest, storage and processing. APGM may have negative consequences on the environment, cause problems in the agriculture and have negative economic impact. Transgenes may be introduced to other genotypes of non-GM crop as well as to wild and weedy relatives via gene flow as is the case in traditional agriculture. The introduction of genes from GM crop to wild and/or weedy recipient may introduce novel or enhanced fitness-related traits into ecosystems that consequently increase adaptability to cultivated conditions (e.g. introgression of herbicide tolerance) (Poppy and Wilkinson, 2005). The presence of APGM can have economic consequences, APGM in a non-GM crop may prevent conventional and organic farmers from declaring their products as non-GM. 


\subsection{Sources of APGM}

Several sources are recognized that contribute to APGM, i.e. seed impurities, cross-fertilization between GM and non-GM fields, wild relatives and weedy plants, occurrence of volunteer plants and technical management (mixing in the machinery at sowing and harvesting, seed dispersal at transport) (Figure 1). The degree of cross-fertilization depends on biological characteristics of the donor and recipient plant, mode of pollination and seed dispersal, cross compatibility between crops, wild and weedy relatives, the frequency and density of hybridizing genotypes and the environmental conditions (flowering synchronization, presence of pollinators, wind) (Poppy and Wilkinson, 2005).

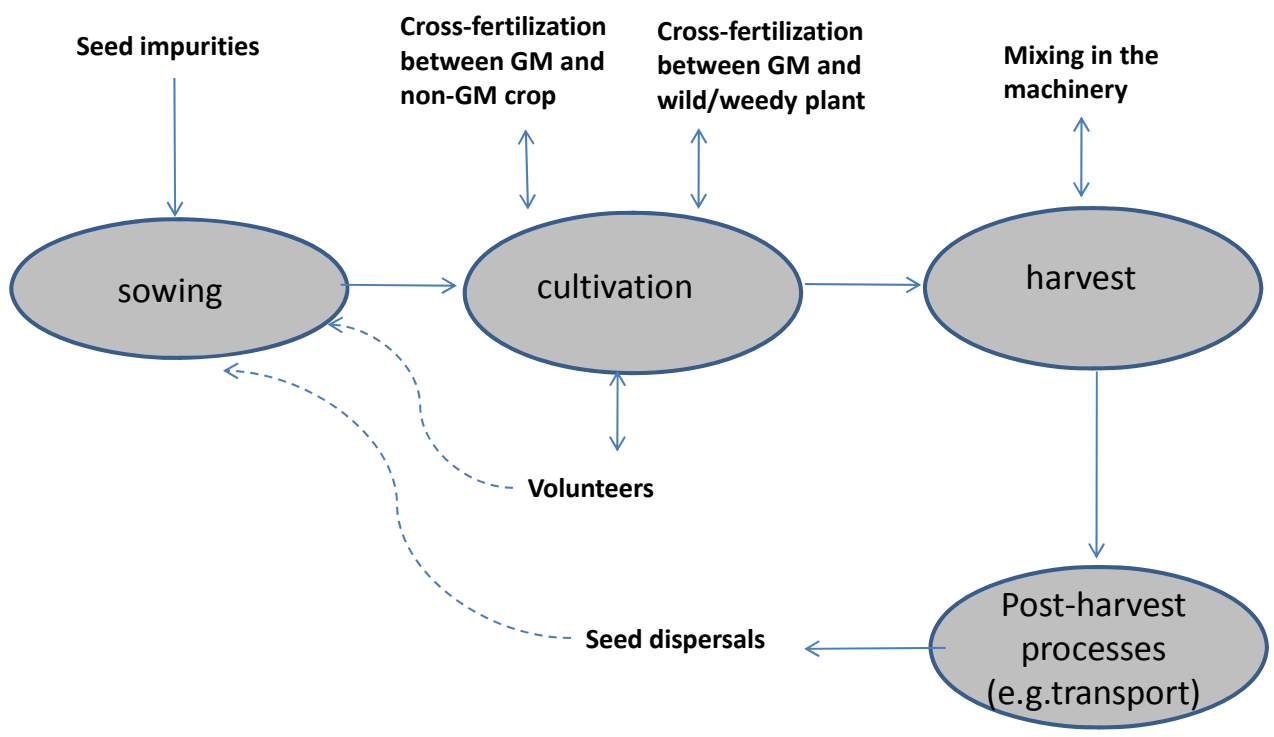

Figure 1: Schematic presentation of APGM sources in non-GM crop in the field (the dotted lines indicate the source of APGM in preceding growing seasons)

Most of the APGM in a conventional maize field comes from cross-fertilization with the neighbouring GM maize fields. Cross-fertilization rate declines with the distance from the pollen donor (GM field). In general, cross-fertilization rate is higher in the border rows and decreases with the distance from the donor towards the centre of the recipient field (Messeguer, 2006). Weekes et al. (2007) reported the maximum of $60 \%$ crossfertilization adjacent to the GM crop. Similarly, Byrne and Fromherz (2003) reported cross-fertilization rates up to $46 \%$ at the border between the two fields with the declination below $1 \%$ within the first $10 \mathrm{~m}$. The analysis of 1174 observation studies with maize in Europe revealed that in $41 \%$ of field studies cross-fertilization rate is below $0.9 \%$ within first $10 \mathrm{~m}$ (Riesgo et al., 2010). The fast decline of cross-fertilization with the distance from the donor was also confirmed in experiments carried out in Slovenia for the situation of small field sizes (GM variety was simulated with a conventional maize variety differing in grain colour from the recipient non-GM variety) (Rostohar et al., 2008).

Although most of the pollen is deposited close to the donor field, long distance hybridization events may occur. There is evidence that cross-fertilization was detected at distances of 650 meters from a known GM source (Henry et al., 2003; Bannert and Stamp, 2007) and that maize pollen can travel up to several kilometres (Brunnet et al., 2011). However, in such cases the pollen competition from other sources may be strong protection against cross-fertilization events thus lowering GMO levels (Bannert and Stamp, 2007). 
Maize does not have wild or weedy relatives in Europe; therefore the introduction of transgenic material into the wild is unlikely. Maize kernels do not survive low winter temperatures in Central European climatic conditions (Luna et al., 2001), but may occur as volunteers in warmer climates (e.g. Spain) (Palaudelmas et al., 2009).

The level of APGM that comes from the seed impurities varies due to flowering coincidence of the two varieties and climatic conditions. If the varieties are of different maturity, the level of APGM in the harvest is reduced (Njontie et al., 2011). If assuming the worst case presence of seed impurities $(0.5 \% \mathrm{GM}$ in non-GM seeds), the APGM from the field (cross-fertilization at the field) and post-field processes (mixing at harvest and inpost-harvest processes) should not exceed more than $0.4 \%$ (Sanvido et al., 2008). The contribution of APGM due to contamination of the machinery can be minimized by dedicating the machinery exclusively for GM production or by properly following the instruction for cleaning (thorough cleaning between the GM and non-GM sowing and harvesting).

One of the possibilities to reduce transfer from GM to non-GM crop could be the introduction of transgene to organelle instead of to nuclear genome. The chloroplast genetic engineering has been successful in some species (tobacco, soybean etc.), but not yet in maize (Clarke and Daniell, 2011). Another alternative is the induction of cross-incompatibility between maize genotypes, but due to difficulties in breeding, this technique is still in its infancy. Another option could also be to use cytoplasmic male sterility for the production of unviable pollen in maize (Munsch et al., 2007; Weider et al., 2007).

\subsection{Parameters influencing APGM}

From a number of field trials the most important parameters influencing the APGM were identified that were used for the development of preventive coexistence measures and are described in the following sub-sections.

\subsubsection{Flowering synchrony}

The synchrony of flowering between GM and non-GM fields contributes to higher cross-fertilization rates
(Westgate et al., 2003, Halsey et al., 2005, Goggi et al., 2006, Angevin et al., 2008). Therefore different planting dates are proposed to minimize the chance of unintended cross-fertilization in the climate where wide sowing interval is manageable. A four to five day shift leads to a $25 \%$ reduction of cross-fertilization rate and a six day shift leads to a $50 \%$ reduction (Della Porta et al., 2008). Up to 10 days difference in planting dates declines the cross-fertilization rate up to $65 \%$ and up to $70 \%$ when there is more than 10 days difference (APROSE, 2004).

\subsubsection{Isolation distances}

Statistical analysis of different field trials with maize revealed that an isolation distance of $30 \mathrm{~m}$ between GM and non-GM field results in cross-fertilization value below $0.9 \%$ at $95 \%$ probability (Pla et al., 2006; Sanvido et al., 2008; Devos et al., 2009; Riesgo et al., 2010). Implementation of isolation distance of $40 \mathrm{~m}$ is sufficient to keep APGM below 0.9\% with 99\% probability (Riesgo et al., 2010). For silage maize Sanvido et al. (2008) propose to shorten the isolation distance by factor 2.5 due to the dilution of the transgenic part in harvest. The factor 2.5 is used when an average proportion of $40 \%$ grain in the completely dry plant tissue is assumed but it depends on the varieties and stages of maturity at harvest. Proposed isolation distances can be reduced when additional measures are applied to minimize the cross-fertilization events.

\subsubsection{Wind}

Different field studies show that cross-fertilization greatly depends on wind conditions (direction and speed). Wind direction has a strong influence on cross fertilization rates at certain distances as shown in Table 1. However, there are also some reports of inconsistent correlation between the wind direction and crossfertilization rate. The maximum cross-fertilization rate did not always coincide with the area of prevailing wind (Della Porta et al., 2008; Lahghof et al. 2008). In such cases, wind peaks in critical days may explain the results (Feil and Schmid, 2002; Halsey et al., 2005). Therefore, the adoption of data from different local climatic condition should be applied carefully. 
Table 1: Distances at which different cross-fertilization rates are achieved depending on wind direction

\begin{tabular}{|l|l|l|}
\hline \multicolumn{2}{|l|}{ WIND DIRECTION } & \multirow{2}{*}{ REFERENCES } \\
\cline { 1 - 2 } DOWNWIND & UPWIND & \\
\hline $10 \mathrm{~m}^{\mathrm{a}}$ & $2 \mathrm{~m}^{\mathrm{a}}$ & Messeguer et al., 2005 \\
\hline $10 \mathrm{~m}^{\mathrm{a}}$ & $2 \mathrm{~m}^{\mathrm{a}}$ & Melé et al., 2004 \\
\hline $10-12 \mathrm{~m}^{\mathrm{b}}$ & $5-7 \mathrm{~m}^{\mathrm{b}}$ & Bénétrix and Bloc, 2003 \\
\hline $54-66 \mathrm{~m}>0.1 \%$ & $12-13 \mathrm{~m}^{\mathrm{b}}$ & Langhof et al., 2008 \\
\hline
\end{tabular}

a - below the $0.9 \%$ of cross-fertilization rate

${ }^{b}$ - below the $1.0 \%$ of cross-fertilization rate

\subsubsection{Size and shape of the donor and recipient field}

The cross-fertilization rate in an individual field is the result of interaction between different fields (GM and non-GM) and depends on the position of fields in the landscape (Messeguer, 2003a; Viaud et al., 2008). Low donor to receptor ratio leads to lower cross-fertilization rates due to large receptor pollen cloud competing with small incoming cloud (Messeguer, 2003b). Weber and Bringezu (2005) concluded that overall crossfertilization rate does not exceed $0.9 \%$ if the recipient and the donor fields are of the same size, while Melé (2004) reported the decrease for $50 \%$ when the size of the recipient field increased from 0.25 ha to 1 ha. The report of Bannert et al. (2008) showed some unexpected results for small fields. For the field situation with the donor/receptor ratio 3.6:1, higher rates of crossfertilization at the receptor field were expected due to lower ratio to the pollen donor; however, values were almost identical at all distances to the pollen donor. This could be explained with the fact that most of the crossfertilization events occurred within the first $6 \mathrm{~m}$ from the donor, irrespective of the donor size; so as long as the receptor and the donor field are wider than $6 \mathrm{~m}$ the ratio of donor to receptor is irrelevant. When up scaling from field to the landscape level, field geometry becomes less crucial while the importance of spatial interaction among the fields is increasing (Viaud et al., 2008). The orientation of fields is also very important, since the edge effects may contribute considerably to the average cross-fertilization rates in the whole receptor field. Langhof et al. (2008) pointed out that pronounced edge effects contribute disproportionally to the overall GM content of the harvest.

The majority of field trials were performed on adjacent or concentric field layout; however, these results should be carefully transferred to the coexistence measures. First, the pollen from non-GM field reduces the impact of GM pollen due to high competition ability more efficiently than open ground isolation distance (Messeguer et al., 2006; Pla et al., 2006). Second, the decrease of cross-fertilization events in the first $25 \mathrm{~m}$ is more evident in concentric and adjacent field experiments comparing to separate field designs, where such declination is less pronounced (Sanvido et al., 2008).

The topography has an impact on downhill increase of cross-fertilization; however over long distances (more than $17.5 \mathrm{~m}$ ) it does not have a significant impact (Vogler et al., 2009).

\subsection{Prediction of APGM in the field}

The estimation of expected cross-fertilization rates are important for the management of GM and non-GM crops along the supply chain and for the prediction of APGM. A simulation gene flow model for maize, MAPOD was developed for the prediction of impurities in the harvest due to cross-fertilization events under real agronomic and environmental conditions (Angevin et al., 2008; Lavigne et al., 2008). It operates with different variables such as landscape patterns, environmental data, agricultural practices and cultivar characteristics. The results are reported as the expected proportion of GM seed in total seed for non-GM pixel (Viaud et al., 2008). A windows software LandSFACTS was developed that simulate crop allocation and crop spatial-temporal arrangements within agricultural landscapes (Messéan et al., 2009). The LandFlow-gene is a generic gene flow modelling platform that operates for maize and rapeseed and predicts the adventitious presence of GM in non-GM fields under different conditions of GM adoption. Within the SIGMEA project a decision support tool called SMAC Advisor was developed to assess the coexistence between GM and conventional maize in a given agricultural environment (Bohanec et al., 2007).

The measurement of all parameters that influence crossfertilization rates in real situations, such as field geometry and distribution, biology of a plant, environmental parameters, pre- and post- harvest processes, is not realistic in practice, since all data are not always available. For example, data from one meteorological station may not be representative for the whole region if the landscape is fragmented with diverse topology. Instead, a few parameters shall be measured 
and incorporated in pre-existing databases and used for empirical and simulation modelling.

One of the strategies to minimize the ex-post consequences in the supply chain is the estimation of APGM in a non-GM crop pre-harvest. Appropriate sampling methods are needed to accurately predict the APGM in the field (Pla et al., 2006, Allnutt et al., 2008). The main difficulty for the development of sampling schemes in the field is obtaining a representative sample from a heterogenous matrix, as the field is. Lowering the threshold aggravate reliable prediction with acceptable measurement certainty. The accuracy of estimation of cross-fertilization rates depends on the number of samples taken, which is in direct correlation with the labour and costs. A simple random sampling was found the most feasible for the collectors and accurate in the estimation of true threshold. Šuštar-Vozlič et al. (2010) developed a sampling approach for determination of the GMO presence at the field level. It is based on the use of fitting functions to estimate approximate distances where sampling is performed.

\section{PREVENTIVE MEASURES FOR COEXISTENCE IN MAIZE}

Different co-existence measures are implemented in order to minimize the APGM in conventional and organic crops. The objective of reducing the APGM in non-GM products is to minimize the impact on the environment and to prevent the economic loss. Preventive measures for maize in the field include i) the use of certified seeds, ii) scheduling different flowering periods (flowering asynchrony), iii) using isolation distances and barrier zones, and iv) implementing good agricultural practice (crop rotation, optimal soil preparation, adequate cleaning and separate use of machinery). One of the most discussed safety measures for minimizing APGM in the field are isolation distances and barrier zones (Devos et al., 2005).

\subsection{Isolation distances}

The isolation distances proposed or imposed by different EU member states for maize range from $15 \mathrm{~m}$ in the Sweden to $800 \mathrm{~m}$ in Bulgaria (Devos et al., 2009; Riesgo et al., 2010). To maintain genetic purity in seed producing programs for conventional maize the minimum separation distance of $200 \mathrm{~m}$ is prescribed in EU. For the cultivation of pharmaceutical GM maize plants at least $1.6 \mathrm{~km}$ is required (Stevens et al., 2004).

The proposed isolation distances by national authorities are not always science based but are compromise between science, social and political demands therefore adequate isolation distances remain a subject of controversy among scientist and regulators (Sanvido et al., 2008). Isolation distances are sometimes also economically not proportionate and demand great effort for management. As for example, in the case of monoculture in a region with small farms and fragmented landscape (as is the case in Slovenia), fixed isolation distances are not manageable in practice because they are not proportionate to agricultural heterogeneity. The prescribed minimal isolation distance for maize in Slovenia is $600 \mathrm{~m}$, which would be difficult to implement for majority of maize fields. In such cases, large distances may also have negative economic effect because they contribute to domino effect that impose severe burden on GM crop production and are not proportional to the farmer's basic economic incentives (Demont et al., 2008). The drastic consequence would also be the abandonment of GM production in a certain area.

\subsection{Barrier zones}

Barrier zones are planted with any plant species that physically limit pollen movement of a donor plant. When the barrier zone is planted with the same but nonGM species as GM donor, it is called buffer zone. There are at least two different options to manage gene flow from GM fields using buffer zones; one is with the exclusion of first few rows in the non-GM fields and the other is planting the non-GM border in the GM field.

In order to maintain the cross-fertilization rate below $0.9 \%$ using the buffer zones several facts should be considered:

- with the increased distance between the GM and non-GM field the number of border rows decreases (Gustafson et al., 2006);

- the legal threshold $(0.9 \%)$ can be obtained by planting buffer zones within first $20 \mathrm{~m}$ or even less, depending on samples taken - upwind or downwind (Bannert and Stamp, 2005; Melé 2004, Weber and Bringezu, 2005);

- for the receptor field of 1 ha and the donor field of 4 ha or larger the use of border rows of $20 \mathrm{~m}$ in combination with isolation distance results in crossfertilization rate less than $0.9 \%$ (Messéan et al., 2009) and

- separate harvesting of the first $10 \mathrm{~m}$ border rows in the receptor adjacent to 1 ha donor are effective to keep the cross-fertilization below the threshold 0.9\%, (Gustafson et al., 2006). 
Instead of using buffer zone a barrier, i.e. non-maize crop could be planted. The study of Langhof et al. (2008) included clover-grass as short crop and a sunflower as a tall crop. The comparison of the effectiveness of the two crops showed that the crossfertilization rates downwind did not differ between the crops. They concluded that the height of a crop is not a sufficient criterion for efficient reduction of gene flow and that the architecture of leaf and other organs is very important criterion. Several authors (Aylor et al., 2003; Goggi et al., 2006) propose buffer zones as more efficient measure for managing coexistence than barriers zones. Barrier, non-maize rows do not compete with the donor pollen, while the maize buffer rows are a source of additional pollen that increases the pollen competition (Wilhelm et al., 2005).

\section{DISCUSSION}

In order to reduce APGM in the non-GM crop, different measures are applied in the supply chain from the field on. In maize, most of the APGM comes from crossfertilization between GM and non-GM crops, from seed impurities, volunteers or because of technical management. Seed impurities are minimized by the use of certified seeds. The volunteers can be managed by crop rotation and optimal soil preparation after harvest and before sowing. At post-harvest processes, adequate cleaning and separate use of machinery for GM and non-GM crop can reduce mixing. In order to minimize APGM different coexistence measures are used. Combination of different measures is applied in different countries according to farming systems, cropping patterns and environmental conditions in the region (Demont et al., 2010).

The experiences with GMO cultivation in Europe have shown that some of the coexistence measures are rigid and difficult to manage in practice. The results of field trials are not always directly transferable between different environments and fluctuate greatly across years and sites within a region. In order to develop reliable guidelines field trials should be conducted in different environments and repeated in years. Such guidelines should incorporate a decision support system.

The coexistence measures should be regulated at different levels with ex ante regulations: i) at the farm level (e.g. the use of isolation distances or barrier zones), ii) at the regional level with respect to heterogeneity of field conditions, managerial expertise, education, market access and pest infestation and iii) at the national level through the policy making and ex post liability schemes (Demont and Devos, 2008; Demont et al., 2008; Demont et al., 2010). Due to heterogeneity in farming, legal and social environments, more flexible coexistence should be handled by the lowest authority possible (Devos et al., 2009).

Demont et al. (2010) proposed free choice for farmers to use different coexistence measures within four different coordination systems (isolation distances, buffer zones and separate harvest of first few rows).
However, it has to be considered that cross-fertilization is not the sole source of APGM in the field, although the main source of APGM comes from cross-fertilization between GM and non-GM plant through gene flow.

Another alternative to manage the coexistence is to establish wide-regions declared as GMO or GMO-free. These areas could then be managed based on private contracts of individual farmers instead of EU or national administrative regulations and recommendations. Furtan et al. (2007) proposed coexistence of three different cropping systems (conventional, GM and organic) within a region with the formation of a private landscape clubs. In such cooperation, organic farmers form a club, GM producers stay outside of the club and the conventional producers stay in the buffer zone and are compensated for their loss. Organic farmers are paying for the costs for functioning of the club from the premium prices of organic products and compensate farmers in the buffer zone. However, this model of coexistence may not be possible in all situations due to many institutional and logistic problems.

Food industries and consumers demand lower acceptable threshold than $0.9 \%$, as low as $0.1 \%$. When demanding lower thresholds we have to consider the opposite effect on coexistence; this could lead to banning of the GMO production in certain regions (Devos et al. 2009). Apart from the coordination of different coexistence measures at the farm and along the supply chain level, the coexistence raises a number of issues at the economic and social level that also need to be carefully addressed. In the future, new management strategies will be needed since novel GM crops are merging with other traits than for food and feed.

From the scientific review, we revealed gaps of existing rules and measures (e.g. large isolation distances) that can be avoided in the future management of GMO in Slovenia and find the possibilities and opportunities for managing different cropping systems for sustainable agriculture. 


\section{ACKNOWLEDGEMENTS}

This work was financially supported by the European Commission through the Sixth Framework Program, Integrated Project Co-Extra (Contract No. 007158) as well as by the Slovenian Research Agency and the Slovene Ministry of Agriculture, Forestry and Food (Grant L4-7573-0401-06).

\section{REFERENCES}

Allnutt, T.R., Dwyer, M., McMillan, J., Henry, C., Langrell, S. 2008. Sampling and modeling for the quantification of adventitious genetically modified presence in maize, Journal of Agricultural and Food Chemistry 56: 32323237.

Angevin, F., Klein, E.K., Choime, C., Gauffreteau, A., Lavigne, C., Messéan, A., Meynard, J.M. 2008. Modelling impacts of cropping systems and climate on maize cross-pollination in agricultural landscapes: The MAPOD model, European Journal of Agronomy 28: 471484.

APROSE. 2004. Evaluation of cross pollination between commercial GM (Mon 810) maize and neighbouring conventional maize fields, In: Analytical survey of 14 commercial Bt fields in 2003 by Monsanto, Nickersons and Pioneer Hi-Bred International, presented to the Spanish Bio-Vigilance Commission. Unpublished.

Aylor, D.E., Schultes, N.P., Schields, E.J. 2003. An aerobical framework for assessing cross-pollination in maize, Agricultural and Forest Meteorology 119: 111-129.

Bannert, M., Stamp, P. Cross pollination in maize. 2005. Coexistence and maize - experiences and results from the German 'ErprobunGSanbau' 2004. Conference, Coexistence of GM and non-GM crops, June 9-10, 2005, Zurich, Swiss.

Bannert, M., Stamp, P. 2007. Cross-pollination of maize at long distance, European Journal of Agronomy 27: 44-51.

Bannert, M., Vogler, A., Stamp, P. 2008. Short-distance crosspollination of maize in a small-field landscape as monitored by grain color markers, European Journal of Agronomy 29: 29-32.

Bénétrix, F., Bloc, D. 2003. Mais OGS et non OGS possible coexistence. Perspectives Agricoles No. 294.

Bohanec, M., Messéan, A., Angevin, F., Žnidaršič, M., Džeroski, S.A. 2007. SMAC advisor: a decision-support tool on maize coexistence. Third International Conference on Coexistence between GM and non-GM Agricultural Supply Chains (GMCC-07), 20-21 November 2007, Seville, Spain, pp 119-122.

Brunet, Y., Dupont, S., Delage, S., Garrigou, D., Guyon, D., Dayau, S., Tulet, P., Pinty, J.-P., Lac, C., Escobar, J., Audran, A., Foueillassar, X., 2011. Long-distance pollen flow in large fragmented landscapes. In Press. In: Bertheau, Y. (Ed.), GM and non-GM supply chains coexistence and traceability, Wiley Publishing (in press).
Byrne, P.F., Fromherz, S. 2003. Can GM and non-GM crops coexist? Setting a precedent in Boulder County, Colorado. USA, Journal of Food Agriculture and Environment 1: 258-261.

Coextra project, Sixth Framework Integrated Project. 20052009. GM and non-GM supply chains : their COEXistence and TRAceability, http://www.coextra.eu/

Clark, J.L., Daniell, H. 2011. Plastid Biotechnology for crop production: present status and future perspectives. Plant Molecular Biology 76: 211-220.

Della Porta, G., Ederle, D., Bucchini, L., Prandi, M., Verderio, A., Pozzi, C. 2008. Maize pollen mediated gene flow in the Po valley (Italy): Source-recipient distance and effect of flowering time, European Journal of Agronomy 28: 255-265.

Demont, M., Daems, W., Dillen, K., Mathijs, E., Sausse, C., Tollens, E. 2008. Regulating coexistence in Europe: Beware of the domino-effect! Ecological Economics 64: 683-689.

Demont, M., Devos, Y. 2008. Regulating coexistence of GM and non-GM crops without jeopardizing economic incentives, Trends in Biotechnology 26: 353-358.

Demont, M., Devos, Y., Sanvido, O. 2010. Towards Flexible Coexistence Regulations for GM crops in the EU, EuroChoices 9: 18-24.

Devos, Y., Reheul, D., De Schrijver, A. 2005. The coexistence between transgenic and non-transgenic maize in the European Union: A focus on pollen flow and crossfertilization, Environmental Biosafety Research 4: 71-87.

Devos, Y., Demont, M., Dillen, K., Reheul, D., Kaiser, M., Sanvido, O. 2009. Coexistence of genetically modified (GM) and non-GM crops in the European Union, Agronomy for Sustainable Development 29: 11-30.

Feil, B., Schmid, J.E. 2002. Dispersal of Maize, Wheat and Rye Pollen. A Contribution to Determining the Necessary Isolation Distances for the Cultivation of Transgenic Crops., Shaker Press, Aachen, Germany.

Furtan, W.H., Güzel, A., Weseen, A.S. 2007. Landscape Clubs: Co-Existence of Genetically Modified and Organic Crops, Canadian Journal of Agricultural Economics 55: 185-195.

GMO compass. 2010. http://www.gmo compass.org/eng/agri biotechnology/gmo_planting/ (20.8.2011)

Goggi, A.S., Caragea, P., Lopez-Sanchez, H., Westgate, M.E., Arritt, R.W., Clark, C.A. 2006. Statistical analysis of 
outcrossing between adjacent maize grain production field, Field Crops Research 99: 147-157.

Gustafson, D.I., Brants, I.O., Horak, M.J., Remund, K.M., Rosenbaum, E.W., Soteres, J.K. 2006. Empirical Modeling of Genetically Modified Maize Grain Production Practices to Achieve European Union Labeling Thresholds, Crop Science 46: 2133-2140.

Halsey, M.E., Remund, K.M., Davis, C.A.; Qualls, M., Eppard, P.J., Berberich, S.A. 2005. Isolation of Maize from Pollen-Mediated Gene Flow by Time and Distance, Crop Science 45: 2172-2185.

Henry, C., Morgan, D., Weekes, R., Daniels, R., Boffey, C. 2003. Farm scale evaluations of GM crops: monitoring gene flow from GM crops to non-GM equivalent crops in the vicinity: part I: forage maize. DEFRA report EPG 1/5/138. http:/www.defra.gov.uk/environment/gm/ research/pdf/epg_1-5-138.pdf

Langhof, M., Hommel, B., Hüsken, A., Schiemann, J., Wehling, P., Wilhelm, R., Rühl G. 2008. Coexistence in Maize: Do Nonmaize Buffer Zones Reduce Gene Flow between Maize Fields? Crop Science 48: 305-316.

Langhof, M., Hommel, B., Hüsken, A., Njontie, C., Schiemann, J., Wehling, P., Wilhelm, R., Rühl, G. 2010. Coexistence in Maize: Isolation distance in Dependence on Conventional Maize Field Depth and Separate Edge Harvest, Crop Science 50: 1496-1508.

Lavigne, C., Klein, E.K., Mari, J.F., Le Ber, F., Adamczyk, K., Monod, H., Angevin, F. 2008. How do genetically modified (GM) crops contribute to background levels of GM pollen in an agricultural landscape ? Journal of Applied Ecology 45: 1104-1113.

Luna, V., Figueroa, M., Baltazar, B., Gomez, L. Townsend, R., Schoper, J. 2001. Maize pollen longevity and isolation distance requirements for effective pollen control, Crop Science 41: 1551-1557.

Melé, E. 2004. Spanish study shows that coexistence is possible, ABIC 3: 2, http://www.abic2004.org/download/ ABIC2004_newsletter_no3.pdf

Messéan, A., Squire, G., Perry, J., Angevin, F., Gomez, M., Zownend, P., Sausse, C., Breckling, B., Langrell, S., Dzeroski ,S., Sweet J. 2009. Sustainable introduction of GM crops into European agriculture: a summary report of the FP6 SIGMEA research project, Oléagineux, Corps Gras, Lipides, 16: 37-51.

Messeguer, J. 2003a. Gene flow assessment in transgenic plants. Plant Cell Tissue and Organ Culture 73: 201-212.

Messeguer, J. 2003b. Evaluation of gene flow in a commercial field of maize, In: Boelt B (ed) Proceedings of the GMCC-03-1 ${ }^{\text {st }}$ European Conference on Co-existence of Genetically Modified Crops with Conventional and Organic Crops, Helsingør, 13-14 November 2003, pp 220.

Messeguer, J. 2005. Cross-fertilization in maize with the cultivation of Bt-maize in Spain. Conference on Coexistence of GM and non-GM crops, Agroscope FAL Reckenholz, Swiss Federal Research Station for
Agriculture and Agroecology, Zurich, Switzerland, http://pure.au.dk/portal/files/327262/Abstract_book.

Messeguer, J., Peñas, G., Ballester, J., Bas, M., Serra, J., Salvia, J., Palaudelmàs, M., Melé, E. 2006. Pollenmediated gene flow in maize in real situations of coexistence, Plant Biotechology Journal 4: 633-645.

Munsch, M., Camp, K.-H., Hüsken, A., Christov, N., Fouiellassar, X., Stamp, P. 2007. The Plus-Hybrid system in maize: biocontainment of transgenic pollen and grain yield increase, in: Stein A.J., Rodríguez-Cerezo E. (Eds.), Book of abstract of the third International Conference on Coexistence between Genetically Modified (GM) and non-GM-based Agricultural Supply Chains, European Commission, pp. 229-230.

Njontie, C., Foueillassar, X., Christov, N., Hüsken, A. 2011. The impact of GM seed admixture on the non-GM harvest product in maize (Zea mays L.), Euphytica 180: 163-172.

Palaudelmas, M., Penas, G., Mele, E., Serra, J., Salvia, J., Pla, M., Nadal, A., Messeguer, J. 2009. Effect of volunteers on maize gene flow, Transgenic Research 18: 583-594.

Pla, M., La Paz, J.L., Peñas, G., García, N., Palaudelmàs, M., Esteve, T., Messeguer, J., Melé, E. 2006. Assessment of real-time PCR based methods for quantification of pollen-mediated gene flow from GM to conventional maize in a field study, Transgenic Research, 15: 219-228.

Poppy, G.M., Wilkinson, M.J. 2005. Gene Flow from GM plants. Blackwell Publishing Ltd., Oxfrod, 241 p.

Regulation (EC) No 1829/2003 of the European Parliament and of the Council of 22 September 2003 on genetically modified food and feed (Text with EEA relevance), Official Journal of the European Union 268: 1-23.

Regulation (EC) No 1830/2003 of the European Parliament and of the Council of 22 September 2003 concerning the traceability and labelling of genetically modified organisms and the traceability of food and feed products produced from genetically modified organisms and amending Directive 2001/18/EC, Official Journal of the European Union 268: 24-28.

Recommendation (EC) 2003/556. 2003. Guidelines for the development of national strategies and best practices to ensure the co-existence of genetically modified crops with conventional and organic farming, Official Journal of the European Union 189: 36-47.

Recommendation (EC) 2010/C 200/01. 2010. Recommendation on guidelines for the development of national co-existence measures to avoid the unintended presence of GMOs in conventional and organic crops, Official Journal of the European Union 53:1-5.

Riesgo, L., Areal, F.J., Sanvido, O., Rodríguez-Cerezo, E. 2010. Distances needed to limit cross-fertilization between GM and conventional maize in Europe, Nature Biotechnology 28: 780-782.

Rostohar, K., Blejec, A., Meglič, V., Šuštar Vozlič, J. 2008. Application of statistical program $\mathrm{R}$ for development of sampling schemes for ensuring coexistence measures in maize fields. In book of Program and abstracts of the 
International Conference on Applied Statistics, 21-23 September 2008, Slovenia, Statistical Society of Slovenia p. 58-59.

Sanvido, O., Widmar, F., Winzeler, M., Streit, B., Szerencsits, E. 2008. Definition and feasibility of isolation distances for transgenic maize cultivation, Trangenic Research 17: 317-335.

Stevens, W.E., Berberich, S.A:, Sheckell, P.A., Wiltse, C.C., Halsey, M.E., Horak, M.J., Dunn, D.J. 2004. Optimizing pollen confinement in maize grown for regulated products, Crop Science 44: 2146-2153.

Šuštar-Vozlič, J., Rostohar, K., Blejec, A., Kozjak, P., Čergan, Z., Meglič, V. 2010. Development of sampling approaches for the determination of the presence of genetically modified organisms at the field level, Analytical and Bioanalytical Chemistry 396: 2031-2041.

Viaud, V., Monod, H., Lavigne, C., Angevin, F., Adamczyk, K. 2008: Spatial sensitivity of maize gene-flow to landscape pattern: a simulation approach, Landscape Ecology 23: 1067-1079.

Vogler, A., Eisenbeiss, H., Aulinger-Leipner, I., Stamp, P. 2009. Impact of topography on cross-pollination in maize (Zea mays L.), European Journal of Agronomy 31: 99102.

ZSGSROKR. 2009. Zakon o soobstoju gensko spremenjenih rastlin $\mathrm{z}$ ostalimi kmetijskimi rastlinami (Act on Coexistence of Genetically Modified Plants with Other Agricultural Plants) Ur.1. RS, št. 41/2009.
Weber, W., Bringezu, T. 2005. Test of coexistence under German field conditions - results from the "Erprobungsanblau" 2004 with Bt-maize. Proc. 2nd Int'1 Conf. on Co-Existence between GM and non-GM based agricultural supply chains, November 2005, Montpellier, France, pp 327, 329.

Weekes, R., Allnutt, T., Boffey, C., Morgan, S., Bilton, M., Daniels, R., Henry, C. 2007. A study of crop-to crop gene flow using farm scale sites of fodder maize (Zea mays L.) in the UK, Transgenic Research 16: 203-211.

Weider, C., Camp, K.-H., Christov, N., Hüsken, A., Fouiellassar, X., Stamp, P. 2007. GM pollen containment by cytoplasmic male sterility (CMS) in maize (Zea mays L.), in: Stein A.J., Rodríguez-Cerezo E. (Eds.), Book of abstract of the third International Conference on Coexistence between Genetically Modified (GM) and non-GM-based Agricultural Supply Chains, European Commission, pp. 65-68.

Westgate, M.E., Lizaso, J.I., Batchelor, W. 2003. Quantitative relationships between pollen shed density and grain yield in maize, Crop Science 43: 934-942.

Wilhelm, R., Meier-Bethke, S., Schiemann, J. 2005. Ergebnisse und Folgerungen aus den Feldversuchen der BBA zur Auskreuzung von transgenem Mais, Vorträge für Pflanzenzühtung 67: 259-266. 